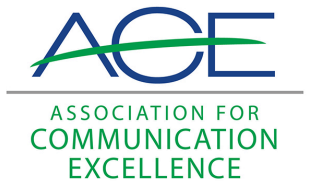

Journal of Applied Communications

\title{
Gauging Distance Education Students' Comfort Level With Technology and Perceptions of Self-Assessment and Technology
} Training Initiatives

Tracy Irani

Ricky Telg

Follow this and additional works at: https://newprairiepress.org/jac (c) (i) (9)

This work is licensed under a Creative Commons Attribution-Noncommercial-Share Alike 4.0 License.

\section{Recommended Citation}

Irani, Tracy and Telg, Ricky (2002) "Gauging Distance Education Students' Comfort Level With Technology and Perceptions of Self-Assessment and Technology Training Initiatives," Journal of Applied Communications: Vol. 86: Iss. 2. https://doi.org/10.4148/1051-0834.2172

This Research is brought to you for free and open access by New Prairie Press. It has been accepted for inclusion in Journal of Applied Communications by an authorized administrator of New Prairie Press. For more information, please contact cads@k-state.edu. 


\title{
Gauging Distance Education Students' Comfort Level With Technology and Perceptions of Self-Assessment and Technology Training Initiatives
}

\begin{abstract}
Distance education has made great strides toward enfranchising nontraditional learners. Yet, while technology has continued to evolve and develop, student support services, especially those focused on technology training and assessment, are still a critical need. This study examined a representative sample of undergraduate, graduate, and postbaccalaureate agricultural students to determine the effect of demographics and prior distance education experience on their perceptions of the need for distance education assessment and training and their comfort level with distance learning technologies. Results indicated that respondents with previous distance education experience rated their comfort level with technology lower than those students taking a distance education course for the first time. A majority of respondents also said they would engage in technology training if their assessment indicated they needed technology skills.
\end{abstract}


Research

\section{Gauging Distance Education Students' Comfort Level With Technology and Perceptions of Self-Assessment and Technology Training Initiatives}

Tracy Irani
Ricky Telg

\section{Abstract}

Distance education has made great strides toward enfranchising nontraditional learners. Yet, while technology has continued to evolve and develop, student support services, especially those focused on technology training and assessment, are still a critical need. This study examined a representative sample of undergraduate, graduate, and postbaccalaureate agricultural students to determine the effect of demographics and prior distance education experience on their perceptions of the need for distance education assessment and training and their comfort level with distance learning technologies. Results indicated that respondents with previous distance education experience rated their comfort level with technology lower than those students taking a distance education course for the first time. A majority of respondents also said they would engage in technology training if their assessment indicated they needed technology skills.

Tracy Irani is an assistant professor of agricultural communication in the University of Florida's Department of Agricultural Education and Communication. She has taught and developed distance education courses using instructional television, videoconferencing and interactive media delivery techniques. Ricky Telg, associate professor in the University of Florida's Department of Agricultural Education and Communication, has taught and developed faculty training materials for distance education. He teaches courses on Web design, computer-based video editing, and news writing. 


\section{Research}

\section{Introduction}

The traditional university classroom has undergone rapid transformation due to the impact of distance education-based technologies, such as compressed video and the Internet. Indeed, corporate management consultants such as Peter Drucker have gone so far as to predict the demise of the traditional university classroom, calling it inefficient and overpriced as compared to distance education delivery methods (Bray, 1999). It's undeniable that for many students, particularly adult learners, the opportunity to take a technology-based distance education course may be very attractive, even essential to obtaining a degree and achieving professional success. But it's also true that adult distance learners may be very different, from the standpoint of experience, personality, and perceptions, than traditional "campus-based" university students.

Research has shown that most distance learners tend to be adults looking to return to school after an absence or to obtain a credential useful in furthering their careers. Increasing numbers of distance learners are also elderly, minority, disabled, or English-as-a-second-language students. Studies of distance education student demographics (National Center for Education Statistics, 1998) indicate that a majority of adult distance learners are female, are older than traditional students, and live 50 or more miles from the originating campus (Thompson, 1997). In addition, they may have family and work responsibilities that cause them to learn differently, perform differently, and have different perceptions and expectations about their course experiences than traditional students (Sheets, 1992).

Studies suggest that distance education may be an effective alternative for some students because it is more flexible than conventional approaches to education (Mandie-Filer, 1988). Studies over the years have shown that students who have taken technology-delivered courses through various media (computers, videotape, satellite, and interactive video) have performed, in terms of final course grades, as well or better than their counterparts in "traditional" classrooms (Moore $\mathcal{E}$ Thompson, 1997). However, because of their experiences with technology and life experiences, distance learners may react to a course differently, potentially causing them to have more difficulties in achieving scholastic success than their on- 


\section{Research}

campus counterparts. A reason for this may be that a significant proportion of adult student learners enroll in courses at a distance with little or no experience of distance learning, and/ or the technological delivery format (Wood, 1996). Wood suggested that such students are at greater risk of doing poorly unless they are identified and helped to develop survival skills early on. Indeed, attrition rates of distance education students far exceed attrition rates of students taught in a traditional format (Parker, 1994).

Reflecting on this issue, McAlister (1998) concluded that provisions need to be made to avoid a "revolving door" in which distance students are allowed to enroll, flounder, and fail. Indeed, developing a more accurate understanding of those factors that may potentially influence perceptions and performance of distance education students, positively or negatively, has long been a goal of distance education researchers. Literature in the field of distance education is, for example, replete with studies to demonstrate the effectiveness of interactive telecommunication (ITV) in terms of student performance (Chu \& Schramm, 1975; Russell, 1992; Whittington, 1987). In addition to performance, researchers have also attempted to measure students' attitudes and perceptions about such topics as the overall distance education experience, technology used, instructional methods, and interaction techniques (Biner, 1993; Diebel, McInnis, $\mathcal{E}$ Edge, 1998; Sorensen, 1995). Sorensen wrote that students' primary complaint was poor reception (video and audio), based on technological constraints. Gray and Miller (1999) found that age appeared to be an attitudinal factor, relating to desired interaction levels in distance education courses distributed by videotape and an interactive video network. Older students in the study placed a higher value on learner-content interaction and learner-interface interaction than did younger students.

\section{Technology as a Potential Barrier}

Davis, Bagozzi, and Warshaw (1989) made the argument that users' perceptions and attitudes toward perceived use and perceived usefulness of a technology influenced their adoption and usage. Extending from this model, Webster and Hackley (1997) contended that attitude toward technology, perceived usefulness, and attitudes toward distance learning should all be considered as outcomes of the distance education experience. In a study of a course in agricultural experiment design that 


\section{Research}

included both live classroom and distance students, Fenwick, Birck, Delaney, and Hicks (1998) found that both groups of students had a preference for taking classes in the conventional, live classroom setting. The researchers ascribed this attitude to potential lack of student experience with distance education technologies. Galusha (1999) saw technology as a potential barrier for distance learners, both in terms of students having access to appropriate, reliable technologies, as well as potential student concerns related to the technology learning curve and lack of technical assistance and support. Visser and Visser (2000), in a study of the perceived needs of distance education students, found that student support services were a critical need, and one that "has gone largely unmet" (p.110).

\section{Purpose and Objectives}

The objectives of the current study were to (1) assess perceptions of and preferences for commonly utilized distance education technologies held by currently enrolled distance education students in a college of agricultural and life sciences; (2) determine the skills respondents felt were needed to be successful in their course as well as their willingness to participate in specific technical student support services such as student self-assessment and technology training; and (3) assess the effects of previous experience and demographics on students' overall comfort level with distance education technologies.

\section{Methods}

To conduct the study, a convenience sample of undergraduate, graduate, and postbaccalaureate distance education students $(n=31)$ was drawn from a population of 49 students enrolled in distance education classes during the spring 2001 semester. Instrumentation for the survey consisted of a 33item questionnaire that included 20 quantitative items and 13 qualitative open-ended items designed to elicit reflective responses. The survey was reviewed by a panel of faculty experts for face and content validity and adjusted accordingly prior to distribution. Reliability analysis using Cronbach's alpha revealed standardized item alpha for the scale was .84. The open-ended responses from the survey were analyzed and coded for common themes using the constant comparative technique (Glaser, 1978). 
Research

\section{Findings}

Of the students who responded $(n=31), 43.8 \%$ were 37 years of age and older, while $21.9 \%$ were traditional-aged (under 22 years of age) students. Almost two thirds (62.5\%) were female, and $37.5 \%$ were male. The majority of respondents were graduate-level students $(46.9 \%)$, followed by undergraduates (34.4\%), and postbaccalaureates (15.6\%). (As defined in this study, "undergraduates" are students pursuing a bachelor's degree, and "postbaccalaureates" are students who have received a bachelor's degree and are taking graduate courses, but who have not been admitted into a master's degree program.) One student (3.1\%) did not respond to this item. Most students were taking distance education courses at one of the university's research and education centers located around the state (43.8\%); another $34.4 \%$ were taking courses from home.

\section{Student experiences with distance education and distance education technologies}

Students were asked if the course they were taking was their first distance education course. Their responses were evenly divided, with $46.9 \%(n=15)$ of respondents answering that it was their first distance experience, while the same percentage of respondents $(n=15)$ indicated that it was not. One student did not respond to this item. Of those who had previous distance education course experience, $67.7 \%$ had three or more previous courses, while $33.3 \%$ had taken one or two.

Respondents indicated that the primary technology used in the distance education course they were taking was WebCT, followed by interactive videoconferencing, Web, and email. Students were then asked which technology they would prefer in a distance education course. In response to this item, $77.4 \%$ said they would prefer interactive videoconferencing, while $12.9 \%$ preferred videotape, $6.3 \%$ preferred WebCT, and $3.2 \%$ preferred email. (See Table 1.)

Students were also asked to indicate all of the software applications that they found most useful in their distance education course. Three fourths (24) of students found presentation software most useful, and $62.5 \%$ (20) found chat and bulletin board services most useful, while only $28.1 \%$ (9) of respondents found Web page development software, such as FrontPage or Netscape Composer, most useful. 


\section{Research}

Table 1. Primary and Preferred Distance Education Technologies

\begin{tabular}{lrc}
\hline Technology & $\mathbf{n}$ & Percentage \\
\hline Primary technology & & \\
WebCT & 23 & 74.2 \\
Interactive videoconferencing & 6 & 19.4 \\
Web & 1 & 3.2 \\
Email & 1 & 3.2 \\
& & \\
Preferred technology & & \\
Interactive videoconferencing & 24 & 77.4 \\
Videotape & 4 & 12.9 \\
WebCT & 2 & 6.5 \\
Email & 1 & 3.2 \\
& &
\end{tabular}

In response to the question, "Which skill is the most important for a student in a distance education course?" $36.7 \%(11)$ of respondents felt that discipline was most important; $20 \%$ (6) named Web searching; 20\% (6) chose email use; and 10\% (3) picked file attaching. When asked if, at the beginning of the semester, they believed they were skilled enough in these areas to succeed in the course, $84.4 \%$ (27) of respondents indicated that were, while only $9.4 \%$ (3) said they were not. Yet $43.8 \%$ (14) of respondents also indicated that they experienced some form of frustration during their course experience; $25 \%$ of these (8) indicated that their frustration was technologically oriented. Follow-up, open-ended responses elicited the reasons for their frustration, including "difficulties in downloading documents from WebCT," "too hard to participate," "very hard to register," and "time consuming, interaction too hard."

\section{Desire to utilize student self-assessment and training in technology tools}

In order to assess respondents' desire to participate in student support services activities, respondents were asked specifically about their willingness to participate in student self-assessment and technology training services. Self-assessment was defined as "a self-assessment that could indicate your suitability for taking and completing a distance education course." Responses indicated that the majority, 65.6\% ( $n=21)$, would not be interested in self-assessment, while $31.1 \%(n=10)$ would be. Technology training was linked to 


\section{Research}

assessment through a question worded as follows: "If the assessment indicated you need some technology skills to be better prepared to complete the course, would you seek training in these technology skills?" $71.9 \%(n=23)$ indicated that they would engage in technology training if their assessment indicated they needed technology skills, while $21.9 \%$ ( $n=$ 7 ) indicated that they would not engage in training.

\section{Student comfort level with technology}

To assess students' comfort level with technology, a fiveitem, subscale index was utilized. Items incorporated into the scale asked respondents to assess their comfort level with five commonly used distance education technologies via a fivepoint Likert-type scale that ranged from 1 = "highly uncomfortable" to 5 = "highly comfortable." Students were most comfortable with interactive videoconferencing and least comfortable with videotape delivery. (See Table 2.)

It was hypothesized that experience of distance education would have a significant impact on students' comfort level with distance education technology. ANOVA results indicated a significant difference in comfort level between those who had previous distance education course experience as opposed to those students who did not, $F(1,30)=4.97, \mathrm{p}<.04$. Interestingly, comparison of means indicated that students with course experience rated their comfort level with technology lower $(M$ $=3.82, \mathrm{SD}=1.14)$ than students who were taking a distance education course for the first time $(M=4.11, S D=1.07)$.

Main effects were also predicted for the effect of educational level, gender, and age on respondents' comfort level with

Table 2. Students' Comfort Level with Distance Education Technologies

\begin{tabular}{lcc}
\hline Technology & Mean & SD \\
\hline Interactive videoconferencing & 4.15 & .99 \\
WebCT & 4.09 & 1.11 \\
Web & 4.04 & 1.21 \\
Email & 4.04 & 1.56 \\
Videotape & 3.96 & 1.37 \\
\hline
\end{tabular}

${ }^{1}=$ "highly uncomfortable" to 5 = "highly comfortable."

Standardized item alpha for the resulting index was .80 . 


\section{Research}

distance education technologies. One-way ANOVA results showed significant differences between males and females, $F(1,29)=6.33, p<.02$ and undergraduates,

postbaccalaureates, and graduate students, $\mathrm{F}(1,29)=4.44$, $\mathrm{P}$ $<.02$ in terms of their comfort level with distance education technologies. No significant differences were observed for the effect of age on comfort level. Comparison of means indicated that males were significantly lower in comfort level $(M=3.11$, $\mathrm{SD}=1.55)$ than females $(M=4.23, \mathrm{SD}=.91)$.

Comparison of means using Scheffe's test showed that graduate students rated themselves as significantly higher in comfort level than undergraduates and postbaccalaureates, and postbaccalaureates rated themselves as significantly lower in comfort level. (See Table 3.)

\section{Discussion}

In this study, results indicated that respondents were highly comfortable with the various technologies used in the classes, yet when asked, they said they would prefer an interactive videoconferencing course over a course delivered by other technologies. This may be because of the more personal nature of interactive videoconferencing, where faculty and students can see each other by television in real time. More women than men were comfortable with the technologies used in their courses. Additional research needs to be conducted to further investigate why women may feel more comfortable with distance education technologies.

Students who had taken one or more distance education courses previously felt less comfortable with the technologies than those who were taking a distance education course for the first time. This could be because first-timers did not know what

Table 3. Effect of Educational Level on Comfort Level with Distance Education Technologies

\begin{tabular}{lrrr}
\hline Ed level & Mean & n & SD \\
\hline Graduate & 4.40 & 15 & .70 \\
Undergraduate & 3.76 & 9 & .97 \\
Postbaccalaureate & 2.96 & 5 & 1.57 \\
\hline
\end{tabular}

Total 3.82

30

1.28 


\section{Research}

was involved in distance education course delivery and interaction and had not experienced technical problems or issues relating to mediated education that the others with previous distance education courses may have had.

In addition, graduate students were more comfortable with distance education technologies than undergraduate or postbaccalaureate students. This is not surprising, considering that people pursuing their master's or doctorate degrees probably have access to computers and related technologies and have used them in their careers to communicate and interact with colleagues in their office or, conceivably, around the world. Postbaccalaureate students may not have had the opportunities to work with distance education technologies while they were undergraduates, which may explain their anxiety in their distance education courses.

Interestingly, respondents initially did not want to take selfassessments that might help predict their likelihood of distance education success. However, they said they would be willing to undergo technology training, if a lack of technical skills was identified in a self-assessment. This may indicate that, although students may perceive of a distance education course as they would a traditional course in terms of content delivered, they are not necessarily completely confident in their technical abilities to succeed in a technology-mediated course. One recommendation for universities engaged in distance education would be to provide students a voluntary, nonthreatening self-assessment-especially one dealing with technology skills-to allow them to identify areas in which they may need additional skills or knowledge, followed up by information on technology training options.

Results from this study indicate that nontraditional students are still the "norm" for distance education courses. Students, overall, felt comfortable with technologies used to deliver distance education courses, but students pursuing advanced degrees were more comfortable with these technologies. Results from the study indicate that universities should invest resources to help all students identify areas where they may need technical skills-building in order to succeed as distance education students. Although respondents in this study did not initially want to take a self-assessment, the idea of providing students with the opportunity to take a self-analysis should be investigated more closely. Any action that would assist stu- 


\section{Research}

dents in becoming more successful in a mediated education environment, would, it could be assumed, have a salutary effect on both the students and the distance education program in which they are enrolled.

\section{References}

Biner, P. (1993). The development of an instrument to measure student attitudes toward televised courses. The American Journal of Distance Education, 7(1), 62-73.

Bray, H., (1999). Virtual campus. The Boston Globe Magazine, Apr 11, 8-16.

Chu, G. \& Schramm, W. (1975). Learning from television: What the research says. (ERIC Document Reproduction Service, ED 109 985).

Davis, F.D., Bagozzi, R.P., \& Warshaw, P.R. (1989). User acceptance of computer technology: a comparison of two theoretical models. Management Science, 35, (8), 982-1003.

Diebel, P.L., McInnis, M.L., \& Edge, W.D. (1998, March). Student use and perceptions of distance education technologies. NACTA Journal, 24-31.

Fenwick, J.R., Brick, M.A., Delany, R.,E Hicks, L. (1998). Student perceptions about a live interactive telecommunications course. Journal of Natural Resources and Life Sciences Education, 27, 97. 100.

Galusha, J. M. (1999). Barriers to learning in distance education [Online]. Available: http://www3.ncsu.edu/dox/NBE/galusha.html

Glaser, B. 1978. Theoretical sensitivity. Mill Valley, CA: The Sociology Press.

Gray, T. \& Miller, W.W. (1999). Preferences and experiences of distance learners participating in agricultural distance education courses. Proceedings of the 26th National Agricultural Research Conference, 354-364.

Mandie-Filer, A. (1988). Women in Papua New Guinea: Distance education as a means for educational advancement. In K. Faith (Ed.), Toward new horizons for women in distance education: International perspectives. London: Routledge.

McAlister, S. (1998). Maria's story, a student with "low" qualifications withdraws from higher education. Distance Education, 19(32), 287-298.

Moore, M. G. \& Thompson, M. M. (1997). The effects of distance learning. Revised edition. ACSDE Research Monograph No. 15. University Park, PA: American Center for the Study of Distance Education, The Pennsylvania State University. 
Research

National Center for Education Statistics. (1998). Distance education in higher education institutions: Incidence, audiences, and plans to expand [On-line]. Available: http://nces.ed.gov/pubs98/ 98132.html

Parker, A. M. (1994). Locus of control, demographics and mode of delivery as predictors of dropout from distance education (financial aid). Dissertation Abstracts International, 55(3), 460.

Russell, T. (1992). Television's indelible impact on distance education: What we should have learned from comparative research. Research in Distance Education, 4(4), 2-4.

Sheets, M. (1992). Characteristics of adult education students and factors which determine course completion: A review. New Horizons in Adult Education [On-line], 6 (1). Available: http:// www2.nu.edu/nuri/llconf/conf1995/rezabek.html

Sorensen, C.K. (1995). Evaluation of interactive television instruction: Assessing attitudes of community college students. DEOSNEWS 5(9).

Thompson, M M. (1997). Distance learners in higher education. In C. Gibson (Ed.) Distance Learners in Higher Education, 9-24. Madison, WI: Atwood.

Visser, L. E Visser, Y. L. (2000). Perceived and actual student support needs in distance education. Quarterly Review of Distance Education, 1,(2), 109-117.

Webster, J., E Hackley, P. (1997). Teaching effectiveness in technology-mediated distance learning. Academy of Management Journal, 40 (6), pp. 1282-1309.

Whittington, N. (1987). Is instructional television educationally effective? A research review. The American Journal of Distance Education, 1(1), 47-55.

Wood, H. (1996). Designing study materials for distance students. [On-line]. Available: http://www.csu.edu.au/division/oli/oli-rd/ occpap17/design.htm 